\title{
Making private interests public
}

\section{California may} ask academics

\section{to declare all}

\section{Washington}

Under new regulations proposed by the state's Fair Political Practices Committee (FPPC), research scientists at the University of California will no longer be given a blanket exemption from conflictof-interest regulations covering other state employees.

Until now, scientists have argued that academic freedom protects them from being required to disclose their personal stake in outside companies with which they may be involved. These ground-rules are now being shifted, largely as the result of several well-publicized cases in which faculty members have profited substantially from such linkages.

Last month, at a meeting in Sacramento, the state capital, the members of FPPC voted by three votes to two to require that any scientist who accepts a research contract from a private corporation must declare to the university whether he or she has a financial interest in that corporation.

The University of California had previously volunteered to introduce an internal system requiring scientists to report potential conflicts of interest to their heads of department. The regulations being proposed by FCCP would not only formalize this arrangement, giving the state the authority to check that such reporting is being carried out, but would also require the university to set up internal review panels at each campus to which conflict-of-interest problems would be referred.

The commission's proposal has been published for public comment before its formal adoption, expected early next month. It does not go as far as some of the university's critics would have liked; in particular, a legal aid group known as California Rural Legal Assistance, which has been leading a campaign against research into labour-saving agricultural machinery at the university's Davis campus, had petitioned the commission to require research scientists to declare all their interests in outside corporations.

In their present form, the regulations would permit a scientist to keep confidential his or her stakes in a private company interested in the same area of research if the research were funded by a public agency. The regulations would therefore be more liberal than the full disclosure required of other state officials.

However, if the regulations are approved - and are subsequently accepted by the state's Office of Administrative Law - it would mean that faculty members on all nine campuses of the University of
California could no longer use academic freedom as a reason for exemption from the conflict-of-interest rules.

The law which covers the regulations was passed in the early 1970 s as part of a nationwide movement to "clean up" the actions of state and federal officials in the wake of the Watergate scandals. Its main purpose is to ensure that state of ficials are not in a position to gain financially through links with outside contractors and other corporations in which they may have a personal interest.

Soon after the law was passed, its application to the state university was challenged by the university's board of regents on the grounds that it infringed the academic freedom of faculty members. At the time FPPC, which was set up to administer the regulations, accepted this

\section{Another French}

Molecular biologists in France are sleeping a little less easily this week, following the spectacular resignation of one of their more important political friends, Professor Philippe Laudat, from his post as director-general of the Institut National de la Santé et de la Recherche Médicale (INSERM).

Laudat waited until after the National Colloquium on Science and Technology (see Nature 21 January, p.180) before sending his letter of resignation to the Minister of Health, M. Jack Ralite, and the Minister of Science and Technology, $M$. Jean-Pierre Chevènement. It was against his own "personal ethics", he wrote, after working energetically for the policies of the previous government, to work now for "noticeably different policies".

The ministries appeared surprised. Laudat's resignation was neither desired nor solicited, said a spokesman for the Minister of Health. "All we did was to ask Laudat to take account of the conclusions of the National Colloquium and the regional assizes [which preceded it]."

INSERM will certainly do that now for the new director-general will be $M$. Philippe Lazar, who was chief rapporteur for the colloquium. Lazar is 45, studied at the Ecole Polytechnique and is an epidemiologist interested in the social and economic aspects of health. His star rose with the new government, and his appointment may shift INSERM away from its present strong emphasis on basic biology towards the clinical and softer sciences.

The issues are complex, however. Clinical science in France is generally thought to be weak. Those who work in university hospital clinics are supposed to teach, care for patients and somehow also find time for research. The research suffers. Clinicians are sore that the last argument and allowed an exemption.

Since then, pressure on research workers to establish closer links with the private sector has increased as both state and federal funding has decreased. The consequent growth of linkages between faculty scientists and outside corporations has been particularly noteworthy in the development and exploitation of recombinant DNA techniques and genetic engineering. Frequently, however, this has led to tensions between academic and commercial pressures.

One campus of the university is already involved in a law suit over the ownership of a cell line passed to research workers in the private sector and subsequently patented; another has told an agricultural scientist working on nitrogen fixation that he cannot both remain principal investigator

\section{director resigns}

government increased INSERM's effort in molecular biology (with an eye on its application in industry) whilst neglecting sciences closer to medicine. There is thus a battle for resources within INSERM between the clinical scientists and the pure scientists, a phenomenon not unknown elsewhere.

However, the matter was complicated by Laudat's creation of international panels of experts, which doled out money for certain priority projects. These panels were outside the normal semi-democratic control of INSERM's partially-elected review committees, and inevitably they tended to favour the successful (usually basic) laboratories, to the neglect of the ailing clinical research system.

The strong French scientific trade unions have long demanded that the international committees should be advisory to, and vetted by, INSERM's elected committees - a procedure which Laudat clearly felt would destroy their effectiveness. Since the unions now have much greater leverage on the government, the fear now is that this kind of democratic reform will go ahead with the result that INSERM resources will be spread more evenly and thinly - exactly what Laudat was trying to avoid.

But the government - and Lazar - are unlikely merely to capitulate to union pressure. Chevènement, in particular, is well aware of the ineffectiveness of many university hospital clinics, but he puts it down to inefficient structures, in particular the overbearing power of the "grands patrons", the "gerontocracy" that rules French medical laboratories and according to some - stifles research. This view, together with the minister's determination to boost biotechnology and its base in molecular biology, may in the end refresh French biology rather than set it back. 
on a university project sponsored by a large fertilizer corporation and help run a private research company in which the same corporation has invested considerable capital (see Nature 8 October 1981, p.417).

A representative of the university said last week that the new regulations proposed by FPPC represented an acknowledgement of some of the recent scientific developments affecting university-industry relations "particularly in genetic engineering, which were not foreseen when we went into this business".

The precise form in which scientists will be required to disclose either their own financial interests, or those of their spouse or children, in companies financing their research has still to be worked out by the university. Also under discussion is the way that the new reporting requirements would be policed. Here the conventional procedure at the university is that, although faculty members are under no legal obligation to make details of their outside interests available to the university, they can be barred from promotion or salary upgrading - both of which must be approved by the state - if they do not do as required.

So far, the university has reacted cautiously to the proposed regulations, recognizing that they have considerable support in the political community. One official on the Berkeley campus claimed that, although many faculty members felt they were being unnecessarily penalized for the excessive actions of a few, the general reaction was a reluctant acceptance.

But the debate may not be over. Some faculty members have apparently indicated informally that they may challenge the new regulations in court on the grounds that they constitute an infringement of constitutional rights. California Rural Legal Assistance in turn is suggesting that it, too, may sue the state if it feels that the regulations are not tight enough.

David Dickson

Polish higher education

\section{Whose pigeon?}

Academic freedom cannot be used to combat socialism and to reduce life to anarchy, General Wojciech Jaruzelski told the Sejm (Polish parliament) last week. This was the first meeting of the Sejm since the introduction of martial law. The twohour speech was intended to justify the drastic measures of 13 December.

On the universities, he noted that the "political tensions" of the past year had involved most of the higher education system, and "weakened the pace" of academic work, creating "painful gaps" in study. The "reinstatement of law and order", however, was now creating conditions for normal work in the universities. "We want to continue the democratization of academic life, to ensure the selfgovernment and autonomy of the colleges', he said. The new higher education bill should, he said, go ahead.

In spite of his professed support for autonomy, the general suggested that more government control over research would be necessary. In many institutes, he said, the practical results of research are nugatory, and the "discipline of scientific research" must be increased. In this respect he criticized all three sectors of Polish science - the universities, the Academy of Sciences and the "departmental" institutes belonging to the production ministries. Hitherto the "departmental" sector has been given financial priority and better fringe benefits. A main plank of Solidarity's programme for science and culture had been parity between the three sectors. Now, it appears, the three sectors may at least attain parity in the degree of government control. The state, said Jaruzelski, must reserve for itself the super. vision of the cost-effectiveness of expensive research, and there should be no repetition in the future of "misguided specialist advice"'.

This last remark appears to refer to the grandiose investment projects envisaged by the Poland -2000 programme of the Gierek regime - although for the past 18 months the major criticism aimed by the scientists at Gierek was that he commissioned expert reports, and then went ahead with his plans for political reasons in spite of economic and technical indications to the contrary.

The form that the Polish research structure will now take is unclear from the general's speech, although clearly Solidarity's hopes of block -grants for academic research, with autonomy for the universities in the allocation of available resources seem unlikely to materialize. One possibility much discussed during the past 18 months had been the dissolution of the existing Ministry of Science, Higher Education and Technology, and the combination of the higher education sector with the Ministry of Education and Upbringing to form a single education ministry, as existed in Poland before 1972. In that event, a Ministry of Science and Technology would be created with responsibility for all the "departmental" institutes now belonging to the various production ministries, while the Academy of Sciences would continue with its present quasi-ministerial status.

It is not yet certain that these plans will be frustrated. The combination of science, higher education and technology in a single ministry has so far favoured the appointment of a scientist as minister. The new minister, however, appointed last week to replace Dr Jerzy Nawrocki who resigned soon after the declaration of martial law, is Professor Benon Miskiewicz, a military historian, who, until 1981, was rector of the Adam Mickiewicz University of Poznan. The appointment of a minister from the humanities could be the first step towards the eventual reorganization of the ministry. Vera Rich

\section{Recombinant DNA guidelines Only formality}

Washington

The Recombinant DNA Advisory Committee (RAC) of the US National Institutes of Health (NIH) is to meet in Bethesda, Maryland, next Monday to decide whether to recommend the coup de grâce for federal regulations introduced six years ago to cover research using recombinant DNA techniques.

Many scientists are urging the committee to support a proposal that, as a final step in dismantling regulations initially introduced as protection against potential hazards from such research, would transform them into a voluntary code of practice. Several state and city legislatures, however - most recently the health committee of the California State Assembly - say that if this happens, they may adopt their own stringent regulations.

Judging by past experience, the most likely outcome is that a compromise formula will be worked out by NIH. While reducing the overall stringency of the regulations, this will probably stop short of making them voluntary in the hope of heading off local, more restrictive controls.

Two proposals have been put to $\mathrm{RAC}$ as possible major revisions to the NIH guidelines. The more radical suggestion was originally put forward by $\mathrm{Dr}$ David Baltimore of Massachusetts Institute of Technology and Dr Allan M. Campbell of Stanford University.

In its current form, which committee members agreed at their last meeting in October should be published for public comment, this revision would reduce the recommended containment level for almost all experiments to $\mathrm{P} 1$ physical containment, eliminate all current prohibitions on certain experiments (though retaining two as "admonishments") and abolish the mandatory aspects of the guidelines (see Nature 17 December 1981, p.606, for full details).

A less severe revision has been proposed by RAC member Dr Susan Gottesman, of the National Cancer Institute's Laboratory of Molecular Biology. This would also revise and relax the containment requirements, but the guidelines would remain mandatory, and it would still be necessary for universities and research institutions to operate Institutional Biosafety Committees.

Officials at NIH report that, although both proposals have been widely distributed to the scientific community, the response has been much less than that to previous proposals to liberalize the guidelines made when the public debate about the safety of recombinant DNA techniques was at its height.

Some of those on both sides of the debate are clearly coming to an end of their stamina. "I cannot think of any letter that I 